ISSN 0258-7122

Bangladesh J. Agril. Res. 37(1): 149-158, March 2012

\title{
PROFITABILITY OF BARI RELEASED POTATO (Solanum tuberosum L.) VARIETIES IN SOME SELECTED LOCATIONS OF BANGLADESH
}

\author{
M.A. HAQUE ${ }^{1}$, M. A. MONAYEM MiaH ${ }^{2}$ \\ S. HOSSAIN ${ }^{3}$ AND M. M. RAHMAN ${ }^{4}$
}

\begin{abstract}
Potato is one of the important food crops in Bangladesh. Its demand is increasing day by day. The Tuber Crop Research Centre (TCRC) of BARI released $40 \mathrm{HYV}$ potato varieties and disseminated them in the farmer's fields through different agencies. But most varieties were not adopted well by the farmers due to unknown reasons. Therefore, an attempt was made to assess the level of adoption and profitability of BARI released potato variety at farm level. Data were collected from 150 randomly selected potato farmers from Munshigonj, Bogra and Comilla districts during January-February 2010. The results indicated that $48 \%$ potato areas were covered by Diamant variety, $16 \%$ by Cardinal, $22 \%$ by Granola, and the rest 14\% areas were covered by Binella, Asterix, Provento, Felsina, Multa and Hira. The cost of BARI released potato cultivation was Tk 2, 10,629 and Tk 1, 84,135 per hectare on full cost and variable cost basis. The major share of total cost was for seed (42\%) followed by fertilizer (21\%) and human labour (14\%). The average yield of potato was 26 t/ha with gross margin of Tk 1, 51,003 per hectare. The net return of potato cultivation was Tk 1, 24,509 per hectare. The benefit cost ratios were 1.59 and 1.82 on full cost and variable cost basis. Human labour, land preparation, seed, and irrigation had positive and significant effect on potato production. Nonavailability of HYV seed at proper time, lack of technical knowledge, high price of seed and fertilizer, infestation of insect and diseases, and lack of storage facilities were the major problems of potato production.
\end{abstract}

Keywords: Profitability, potato, cost of cultivation.

\section{Introduction}

Potato (Solanum tuberosum L.) is one of the important vegetables as well as cash crop in Bangladesh. Bangladesh ranks $11^{\text {th }}$ in the world in terms of potato production in 2008 (Hossain and Miah, 2010). In fact, short cycle of potato frees the land for cultivating other crops. In 2008-2009, about 5166.7 thousands metric tons of potatoes have been produced from 395.6 thousands hectares $(2.9 \%$ of total cultivated area) of land in Bangladesh (BBS, 2009). The area and production of potatoes are increasing day by day due to its higher demand and profitability. The annual growth rates of area, production and yield of potato

${ }^{1}$ Principal Scientific Officer, ${ }^{2}$ Senior Scientific Officer, ${ }^{3}$ Chief Scientific Officer, Agricultural Economics Division, Bangladesh Agricultural Research Institute (BARI), Gazipur, ${ }^{4}$ Director, Training and Communication, BARI, Gazipur, Bangladesh. 
were estimated at $7.14 \%, 9.90 \%$ and $2.76 \%$ during $1989-1990$ to $2008-2009$, respectively (Miah et al., 2011).

The Tuber Crop Research Centre of BARI released 40 HYV potato varieties which have good yield potential and tolerant to insect pests and diseases. These released varieties are disseminated in the farmer's fields through different agencies. Most of the varieties are not cultivated by the farmers because of various unknown reasons that need to be identified. Nevertheless, the economic profitability of BARI released potato varieties is not evaluated.

With this view in mind, the present study has been undertaken with the following objectives: (i) to know the level of adoption of BARI released potato varieties at farm level; (ii) to estimate the profitability of BARI released potato varieties; (iii) to evaluate the farmers attitude towards the cultivation of BARI released potato varieties; (iv) to identify the socio- economic constraints of BARI released potato varieties at farm level.

\section{Materials and Method}

Sampling technique: A multi-stage sampling technique was followed in this study to select study areas and sample farmers. In first stage of sampling, three potato growing districts namely Munshigonj, Comilla and Bogra were selected purposively. In the second stage, one Upazila was selected from each district for sample survey. The names of the Upazilas were Sadar under Munshigonj district, Shibgonj under Bogra district and Chandina under Comilla district. In the third stage, a complete list of potato growers were collected from each Upazila and finally a total of 150 potato farmers taking 50 farmers from each Upazila were selected by random sampling technique.

Method of data collection: Data for the present study were collected from sample potato farmers through face to face interview method using a pre-tested interview schedule. Field level data were colleted by the researcher with the help of trained enumerators for the period of January-February, 2010.

Analytical techniques: Both fixed cost and variable cost were taken into account in calculating cost of potato cultivation. Land use cost was calculated on the basis of per year existing lease value of land. Irrespective of potato varieties, the profitability of potato production was examined on the basis of gross margin, net return and benefit cost analysis. The collected data were edited, summarized, tabulated and analyzed to fulfill the objectives of the study. Tabular method using descriptive statistics was mostly used in the study. The following CobbDouglas production function model was used to estimate the contribution of factors to potato production.

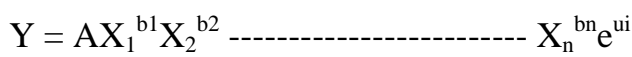

The production function was converted to logarithmic form so that it could be solved by least square method i.e. 
$\ln \mathrm{Y}=\mathrm{a}+\mathrm{b}_{1} \ln \mathrm{X}_{1}+\ldots \ldots \ldots \ldots \ldots \ldots \ldots \ldots+\mathrm{b}_{\mathrm{n}} \ln \mathrm{X}_{\mathrm{n}}+\mathrm{U}_{\mathrm{i}}$

The empirical production function was the following:

$\ln \mathrm{Y}=\mathrm{a}+\mathrm{b}_{1} \ln \mathrm{X}_{1}+\mathrm{b}_{2} \ln \mathrm{X}_{2}+\mathrm{b}_{3} \ln \mathrm{X}_{3}+\mathrm{b}_{4} \ln \mathrm{X}_{4}+\mathrm{b}_{5} \ln \mathrm{X}_{5}+\mathrm{b}_{6} \ln \mathrm{X}_{6}+\mathrm{b}_{7} \ln \mathrm{X}_{7}+\mathrm{U}_{\mathrm{i}}$.

Where, $Y=$ Yield (kg/ha); $X_{1}=$ Human Labor (Man-day/ha); $X_{2}=$ Land preparation cost $(\mathrm{Tk} / \mathrm{ha}) ; \mathrm{X}_{3}=$ Seed $(\mathrm{kg} / \mathrm{ha}) ; \mathrm{X}_{4}=$ Manure $(\mathrm{kg} / \mathrm{ha}) ; \mathrm{X}_{5}=\mathrm{NPK}$ fertiliser; $\mathrm{X}_{6}=$ Insecticide cost $(\mathrm{Tk} / \mathrm{ha}) ; \mathrm{X}_{7}=$ Irrigation cost $(\mathrm{Tk} / \mathrm{ha}) ; \mathrm{A}=$ Intercept; $b_{1}, b_{2}----b_{7}=$ Coefficients of the respective variables to be estimated; and $\mathrm{U}_{\mathrm{i}}=$ Error term.

\section{Results and Discussion}

\section{Adoption of improved potato varieties}

An attempt was made to assess the level of adoption in terms of area coverage of BARI released potato varieties at farm level. The farmers in the study areas adopted BARI released potato varieties such as diamant, cardinal, binella, asterisk, granola, provento, felsina, multa and hira. On an average $48 \%, 16 \%$ and $22 \%$ potato areas were covered by diamant, cardinal and granola variety and the rest $14 \%$ areas were covered by binella, asterix, provento, felsina, multa and hira. It was also observed that area covered by different varieties of potato varied from location to location mainly due to existing cropping patterns and soil types. The major cropping pattern in Munshigonj is Fallow-Potato-Fallow might be due to flood prone low land. Therefore, they cultivate more diamant variety due to its higher demand and yield compared to other varieties. On the other hand, the highly adopted cropping pattern in Bogra is T.aman-Potato-Boro. Therefore, Farmers in Bogra cultivate short duration potato variety granula (60-65 days) more than that of other varieties. About 88\% potato areas in Munshigonj, 13\% in Bogra and $42 \%$ in Comilla were covered by diamant variety, whereas $65 \%$ potato areas in Bogra were covered by granola. Detailed area coverage by BARI released potato varieties has been shown in Table 1.

Table 1. Adoption of BARI released potato varieties at farm level.

\begin{tabular}{l|c|c|c|c}
\multicolumn{1}{c}{ Variety } & Munshigonj & Bogra & Comilla & All areas \\
\hline Diamant & 88 & 13 & 42 & 48 \\
Cardinal & 4 & 20 & 25 & 16 \\
Binella & 2 & - & - & 1 \\
Asterix & 2 & - & - & 1 \\
Granola & - & 65 & - & 22 \\
Provento & 2 & 2 & - & 1 \\
Felsina & 2 & - & 12 & 5 \\
Multa & 1 & - & 6 & 2 \\
Hira & - & - & 15 & 5 \\
Total & 100 & 100 & 100 & 100 \\
\hline
\end{tabular}




\section{Input use pattern}

The human labour used for producing potato was found to be 211 man days per hectare of which $29 \%$ were family supplied. The rest $71 \%$ labours were used on hire basis. That means there are higher scopes of employment for hired labour in potato cultivation. The use of human labor was highest in Munshigonj (250 mandays/ha) followed by Comilla (208 man-days/ha) and Bogra (176 man-days/ha). The average cost of land preparation was Tk 5420 per hectare. The cost of land preparation was higher in Munshigonj compared to other study areas due to use higher labour and higher wage rate (Table 2). The average quantity of seed and manure used by the farmers were $2480 \mathrm{~kg}$ and $7584 \mathrm{~kg}$ per hectare respectively. The seed rate used by the farmers was $65 \%$ higher than the recommended seed rate of $1.5 \mathrm{t} /$ ha (Satter et al., 2005). They used chemical fertilizers like urea, TSP, MoP, zipsum, zink sulphate, and boron at the rate of $314 \mathrm{~kg}, 393 \mathrm{~kg}, 327 \mathrm{~kg}, 77$ $\mathrm{kg}, 2 \mathrm{~kg}$, and $1 \mathrm{~kg}$ per hectare. They used higher doses of urea, TSP and MoP than the recommended doses $(220-250 \mathrm{~kg} / \mathrm{ha}, 120-150 \mathrm{~kg} / \mathrm{ha}$ and $220-250$ $\mathrm{kg} / \mathrm{ha}$ )(BARI, 2005) and also used lower doses of zipsum, zink sulphate and boron than the recommended doses (100-120 kg/ha, 8-10 kg/ha and 8-10 $\mathrm{kg} / \mathrm{ha}$ )(BARC, 2005). Table 2 further reveals that Munshigonj farmers used higher amount of fertilizers compared to other study areas might be due to less confidence on the recommended doses of fertilizers. Earlier study on potato also found that Munshigonj farmers used higher dose of fertilizers (Haq et al., 1995).

Table 2. Input use pattern of potato cultivation in different study areas.

\begin{tabular}{lccccc}
\hline \multicolumn{1}{c|}{ Items } & Munshigonj & Bogra & Comilla & All areas \\
\hline Human labor (man-days/ha): & 250 & 176 & 208 & 211 \\
$\quad$ Family & 72 & 54 & 60 & 62 \\
$\quad$ Hired & 178 & 122 & 148 & 149 \\
Land preparation cost (Tk./ha): & 8799 & 3644 & 3817 & 5420 \\
Seed (kg/ha) & 2793 & 2151 & 2496 & 2480 \\
Manures (kg/ha) & - & 13489 & 9264 & 7584 \\
Fertilizers (kg/ha): & & & & \\
Urea & 380 & 346 & 216 & 314 \\
TSP & 500 & 283 & 396 & 393 \\
MP & 449 & 265 & 267 & 327 \\
Zipsum & 9 & 68 & 155 & 77 \\
Zinc sulphate & - & 7 & - & 2 \\
Boric acid & - & 4 & - & 1 \\
\hline
\end{tabular}




\section{Cost of cultivation}

For calculating the cost of cultivation of potato, all variable costs like human labour, land preparation, seed, manures, fertilizers, insecticides, irrigation, and interest on operating capital were calculated per hectare basis. The fixed cost of potato cultivation included cost of land use and family labour. The cost of land use was calculated on the basis of lease value of land. The total cost included fixed cost and variable cost. The cost of potato cultivation was estimated to be Tk. 2,10,629 and Tk. 1,84,135 per hectare on total cost and variable cost basis, respectively. The major share in total cost was seed (42\%), followed by chemical fertilizers (21\%) and human labour (14\%). The cost of potato cultivation in Munshigonj (Tk. 2,32,283/ha) was found highest followed by Bogra (Tk. 2,05,971/ha) and Comilla (1,93,636/ha) due to the higher cost of human labour, fertilizer and insecticides (Table 3).

Table 3. Cost of production of potato in different study areas.

\begin{tabular}{|c|c|c|c|c|}
\hline \multicolumn{5}{|c|}{ (Figure in Tk./ha) } \\
\hline Items & Munshigonj & Bogra & Comilla & All areas \\
\hline A. Variable Cost: & $203807(88)$ & $179182(87)$ & $169115(87)$ & $184135(88)$ \\
\hline $\begin{array}{l}\text { Land preparation } \\
\text { cost }\end{array}$ & 8799 (4) & $3644(2)$ & $3816(2)$ & $5420(3)$ \\
\hline Hired labour & 26732 (12) & $18351(10)$ & 19097 (10) & 21393 (10) \\
\hline Seed & 85569 (40) & $96804(46)$ & $85458(44)$ & $89277(42)$ \\
\hline Organic manure & - & $6443(3)$ & $4632(2)$ & $3692(2)$ \\
\hline Chemical fertilizers: & $56518(24)$ & 35749 (17) & 39631(20) & 43966 (21) \\
\hline Urea & 4568 & 4150 & 2622 & 3780 \\
\hline TSP & 28037 & 16060 & 21788 & 21962 \\
\hline MP & 23798 & 14331 & 14443 & 17524 \\
\hline Zipsum & 53 & 340 & 778 & 390 \\
\hline Zink & - & 435 & - & 145 \\
\hline Boric acid & - & 433 & - & 144 \\
\hline Insecticides & $12488(5)$ & 10504 (5) & 7450 (4) & 10148 (5) \\
\hline Irrigation & $5863(3)$ & $3200(2)$ & $4926(3)$ & $4663(2)$ \\
\hline $\begin{array}{l}\text { Interest on operating } \\
\text { capital }\end{array}$ & 7838 (3) & 4487 (2) & 4400 (3) & 5575 (3) \\
\hline B. Fixed cost: & 28474 (12) & 26789 (13) & 24220 (13) & 26494 (12) \\
\hline Family labour & $10849(5)$ & 8077 (4) & 8477 (4) & $9134(4)$ \\
\hline Land use & $17625(7)$ & $18712(9)$ & 15743 (8) & $17360(8)$ \\
\hline Total cost $(\mathrm{A}+\mathrm{B})$ & $232281(100)$ & $205971(100)$ & $193335(100)$ & $210629(100)$ \\
\hline
\end{tabular}

Figures within the parentheses indicates percentage of total cost 


\section{Profitability of potato cultivation}

The yield of potato was 26 tons per hectare which was higher than the national average yield (15.43 t/ha) (BBS, 2009). The yield of potato was found to be the highest in Munshigonj (31 t/ha) followed by Comilla (25 t/ha) and Bogra (23 t/ha) due to better management and good soil condition (Table 4). The gross return and gross margin of potato cultivation were Tk 335138 and Tk.1,51,003 per hectare, respectively. Gross margin was found to be the highest in Munshigonj (Tk 1,91,345) followed by Comilla (Tk 15,1607) and Bogra (Tk 110355). The net return of potato cultivation was Tk 1,24,509 per hectare. It was the highest in Munshigonj (Tk 1,62,873) and the lowest in Bogra (Tk 83,566) due to higher gross return. The average benefit cost ratios were 1.59 and 1.82 on full cost and variable cost basis. It was also found that the highest BCR on variable cost received by the Munshigonj farmers followed by Comilla and Bogra farmers due to higher yield and price.

Table 4. Profitability of potato cultivation in different study areas.

\begin{tabular}{lccccc}
\hline \multicolumn{1}{c}{ Items } & Munshigonj & Bogra & Comilla & All areas \\
\hline $\begin{array}{lccc}\text { 1. Total variable cost } \\
\text { (Tk./ha) }\end{array}$ & 203809 & 179182 & 169115 & 184135 \\
2. Total cost (Tk./ha) & 232281 & 205971 & 193335 & 210629 \\
3. Yield (kg/ha) & 30735 & 23163 & 24520 & 26139 \\
4. Price (Tk./kg) & 12.85 & 12.51 & 13.00 & 12.79 \\
5. Gross return (Tk./ha) & 395154 & 289537 & 320722 & 335138 \\
6. Gross margin (Tk./ha) & 191345 & 110355 & 151607 & 151003 \\
7. Net return (Tk./ha) & 162873 & 83566 & 127387 & 124509 \\
8. Benefit cost ratio & & & & \\
$\quad$ Full cost basis & 1.70 & 1.41 & 1.66 & 1.59 \\
$\quad$ Variable cost basis & 1.94 & 1.62 & 1.90 & 1.82 \\
\hline
\end{tabular}

\section{Factors affecting potato yield}

In order to determine the contribution of inputs like human labour, land preparation, seed, manure, NPK fertilizers, insecticide and irrigation for potato production, Cobb-Douglas production function was used. The estimated values of co-efficients and related statistics of Cobb-Douglas production function have been presented in Table 5. All the co-efficients of human labour, land preparation, seed and NPK fertilizer are positive and significant at $1 \%$ level, indicated that $1 \%$ increase in the use of human labor, land preparation, seed and NPK fertilizer, keeping other factors remaining constant would increase the yield of potato by $0.225 \%, 0.076 \%, 0.313 \%$ and $0.386 \%$, respectively. Manure and 
insecticide application had positive impact on the yield of potato but the effects were not significant at desired level of significance. The co-efficient of irrigation was negative and significant at $10 \%$ level.

Table 5. Estimated coefficients and their related statistics of production function for potato.

\begin{tabular}{l|c|c|c}
\hline \multicolumn{1}{c}{ Explanatory Variables } & Co-efficient & t-values & P-values \\
\hline Intercept & $3.326^{* * *}$ & 5.7950 & 0.0000 \\
Human labor $\left(\mathrm{X}_{1}\right)$ & $0.225^{* * *}$ & 3.6977 & 0.0003 \\
Land preparation $\left(\mathrm{X}_{2}\right)$ & $0.076^{* * *}$ & 3.5843 & 0.0005 \\
Seed $\left(\mathrm{X}_{3}\right)$ & $0.313^{* * *}$ & 6.6129 & 0.0000 \\
Manure $\left(\mathrm{X}_{4}\right)$ & 0.026 & 1.1434 & 0.2548 \\
NPK fertiliser $\left(\mathrm{X}_{5}\right)$ & $0.386^{* * *}$ & 5.6004 & 0.0000 \\
Insecticides $\left(\mathrm{X}_{6}\right)$ & 0.021 & 1.1814 & 0.2394 \\
Irrigation $\left(\mathrm{X}_{7}\right)$ & $-0.082^{*}$ & -1.8986 & 0.0597 \\
$\quad \mathrm{R}^{2}$ & 0.80 & - & \\
$\quad \mathrm{F}$ value & $79.74^{* * *}$ & & \\
\hline
\end{tabular}

Note: $* * *$, and $*$ indicate significant at $1 \%$ and $10 \%$ level respectively

The value of the coefficient of determination $\left(\mathrm{R}^{2}\right)$ was 0.80 , which indicated that around $80 \%$ of the variation in yield was explained by the independent variables included in the model. The value of $\mathrm{F}$ was 79.74 which were significant at $1 \%$ level implying that the variation of yield mainly depends on the explanatory variables included in the model.

\section{Farmers' attitude towards BARI released potato cultivation}

Table 6 revealed that about $64 \%$ farmers were willing to increase the cultivation of BARI released potato varieties in the next year. Higher yield ranked top behind the reasons for increasing potato cultivation followed by short duration crop, profitability, and easy production technology. On the other hand, 36\% farmers were not interested to increase the BARI released potato cultivation due to high price of potato seed during sowing period, storage problem, high infestation of insect and diseases, and lack of enough money for potato cultivation.

\section{Problems of potato cultivation}

The farmers in the study areas encountered different problems during potato cultivation. The problems were ranked based on their priority. A brief discussion on various problems has been made in the following sections. 
Non-availability of quality seed: Potato yield largely depends on quality seed. Farmers in the study areas used potato seed from many sources like own source, BADC, market traders, etc. Market traders usually adulterate potato seed for making higher profit. BADC seed is almost scarce to the farmers. Nonetheless, own seed retained for their own use don't fulfill their requirements. Therefore, $70 \%$ of the respondent farmers mentioned non-availability of quality seed at planting time as a first ranked problem.

Table 6. Reasons for increasing BARI released potato varieties for the next year.

\begin{tabular}{|c|c|c|c|c|}
\hline \multirow{2}{*}{ Type of Facility } & \multicolumn{4}{|c|}{$\%$ of farmers } \\
\hline & Munshigonj & Bogra & Comilla & All areas \\
\hline \multicolumn{5}{|l|}{ A. Willingness to increase } \\
\hline 1. Yes & $35(70)$ & $30(60)$ & $32(64)$ & $32(64)$ \\
\hline 2. No & $15(30)$ & $20(40)$ & $18(36)$ & $18(36)$ \\
\hline \multicolumn{5}{|l|}{ B Reasons for increasing } \\
\hline 1. Profitable crop & $20(57)$ & $15(50)$ & 22 (69) & $19(59)$ \\
\hline 2. Higher yield & $25(71)$ & $20(67)$ & $23(72)$ & $23(70)$ \\
\hline 3. Easy production technology & $15(43)$ & $12(40)$ & $18(56)$ & $15(47)$ \\
\hline 4. Short duration crop & $20(57)$ & $25(78)$ & $19(59)$ & $21(66)$ \\
\hline \multicolumn{5}{|l|}{ C. Reasons for not increasing } \\
\hline $\begin{array}{l}\text { 1. High price of seed during } \\
\text { sowing period }\end{array}$ & $12(80)$ & $15(75)$ & $14(78)$ & $14(78)$ \\
\hline $\begin{array}{l}\text { 2. Ignorance about new HYV } \\
\text { potato seed }\end{array}$ & $10(66)$ & $15(75)$ & $12(67)$ & $12(67)$ \\
\hline $\begin{array}{l}\text { 3. Lack of enough money for } \\
\text { potato cultivation }\end{array}$ & $5(33)$ & $6(30)$ & $5(28)$ & $5(28)$ \\
\hline $\begin{array}{l}\text { 4. High infestation of insect and } \\
\text { diseases }\end{array}$ & $8(53)$ & $10(50)$ & $10(56)$ & $9(50)$ \\
\hline 5. Storage problem & $12(80)$ & $15(75)$ & $14(77)$ & $14(78)$ \\
\hline
\end{tabular}

Lack of technical knowledge: Technical knowledge relating to crop cultivation is also crucial for getting higher yield. It optimize input use, saves production cost and increase yield of crops as well as farmers' income. Most respondent farmers in the study areas were suffering from lack of technical knowledge regarding potato cultivation since they used various inputs unwisely. This problem was highly reported by Bogra farmers compared to other areas. In all areas, this problem was reported by $54 \%$ of the farmers in the study areas.

Higher price of fertilizers: Fertilizers are important input for crop production. It increases soil fertility and crop yield. Due to its higher price many small and marginal farmers can not use proper dose of fertilizers and get lower yield. That's 
why, half of the respondent farmers reported higher price of fertilizers to be a problem.

Insect and disease infestation: Late blight (LB) is one of the important potato diseases. The yield of potato is seriously hampered by this disease. Many respondent farmers (42\%) faced this problem during potato cultivation.

Lack of storage facility: Potato is a semi perishable vegetable which needs storage for using it throughout the year. Most small and medium farmers have to sell most of their potatoes immediately after harvesting with lower price. Most of them have little access to the local cold storage because of their small volume. Therefore, lack of storage facility was reported to be a problem by $34 \%$ farmers in the study areas.

Table 7. Constraints to potato cultivation in different study areas (multiple responses).

\begin{tabular}{l|c|c|c|c}
\hline \multirow{2}{*}{\multicolumn{1}{c|}{ Constraints }} & \multicolumn{4}{c}{ \% responses } \\
\cline { 2 - 5 } & Munshigonj & Bogra & Comilla & All areas \\
\hline \multicolumn{1}{c}{ Observation (n) } & $N=50$ & $N=50$ & $N=50$ & $N=150$ \\
1.Non- availability of quality seed & 70 & 74 & 64 & 70 \\
2. Lack of technical knowledge & 44 & 62 & 56 & 54 \\
3. High price of fertilizer & 50 & 52 & 48 & 50 \\
4. Infestation of insects and & 44 & 44 & 42 & 42 \\
diseases & & & & \\
5. Lack of storage facility & 36 & 32 & 36 & 34 \\
\hline
\end{tabular}

\section{Conclusion and Recommendations}

The study has been designed for assessing the farm level adoption and estimating the profitability of BARI released potato varieties in Bangladesh. The study shows that diamant is the highly adopted potato variety in the study areas followed by granola and cardinal. Besides, the cultivation of BARI released potato varieties at farm level is highly remunerative. Farmers' attitudes towards HYV potato production seem to be very positive because most of the farmers wanted to increase potato production in the next year. Although potato cultivation is a profitable venture, it faces various problems. The lack of quality seed is a major problem in higher adoption of HYV potatoes at farm level.

Based on study findings, the following recommendations are put forward for wider adoption of BARI released HYV potato at farm level:

- The quality of HYV seed should be made locally available to the farmers. Government should encourage private seed companies to come 
forward for producing quality seed potatoes. Law enforcing authority should take appropriate action against seed adulteration.

- Motivational campaign through providing training, booklets and other supporting materials to farmers and extension personnel about the HYV potato should be continued.

- More intensive research should be undertaken by the BARI scientists to develop disease and insect-pest resistant potato varieties in the near future.

- Chemical fertilizers with low price should be made available at farm level.

- Storage facility should be developed for the actual farmers to conserve their interest. Therefore, the government should take appropriate steps so that the actual farmers can store their produces to cold storage. Besides, emphasis should also be given to increase the number of cold storage in the country.

\section{References}

BBS (Bangladesh Bureau of Statistics). 2009. Year book of Agricultural Statistics of Bangladesh, Statistics Division, Ministry of Planning, Government of the People's Republic of Bangladesh, Dhaka, Bangladesh.

BARC (Bangladesh Agricultural Research Council). 2005. Fertilizer Recommendation Guide, Published by the Bangladesh Agricultural Research Council, Farmgate, Dhaka-1215.

BARI (Bangladesh Agricultural Research Institute). 2005. Handbook of Agricultural Technology $3^{\text {rd }}$ edition, Gazipur.

Hossain, M.A. and M.A.M. Miah. 2010. Post-harvest losses and technical efficiency of potato storage systems in Bangladesh. Technical Report submitted to FAO Bangladesh. Available at: http://www.fao.org/inpho/content/conpend/text

Huq, A. S. M. A., M. S. Hussain and M. A. Rashid. 1995. Potato production in CDP demonstration area: yield gap analysis. Annual report 1995, Agricultural Ecinomics Division, BARI, Gazipur.

Miah, M. A. M., S. Hossain, T. M. B. Hossain, S. Rahman and et al. 2011. Assessment of potato farmers' perceptions on abiotic stresses and implications for potato improvement research in Bangladesh: a baseline survey. Research report submitted to International Potato Centre (CIP), Lima, Peru.

Satter, M.A., M. M. Rahman, M. H. Rashid, M. S. Ali and M. S. Alam. 2005. Krishi Projukti Hatboi (Hand book on agro technology), $3^{\text {rd }}$ Edition, BARI, Gazipur. 